\title{
Co-efficient of discharge variation for different semi-circular weirs
}

\author{
D. SAI GANGADHARA RAO, T.V. SATYANARAYANA AND H.V. HEMA KUMAR
}

Received : 18.06.2014; Revised : 18.07.2014; Accepted : 02.08 .2014

See end of the Paper for authors' affiliation

Correspondence to :

D. SAI GANGADHARA RAO Department of Agricultural

Engineering and Technology,

College of Agricultural

Engineering, Bapatla,

GUNTUR (A.P.) INDIA
ABSTRACT : Critical flow in control sections prevents the downstream water level and flow conditions from affecting the flow through the critical sections, and the discharge can be computed as a function of the measured upstream head. Measurements of irrigation water flows in field channels have usually been expensive, too often of questionable accuracy and otherwise difficult to apply to all field situations. The techniques available in open channel hygrometry are the use of hydraulic structures (devices), velocity-area methods, dilution techniques and slope-hydraulic radius and area methods. Considering the constraints in the measurements of low discharges in open channels, hydraulic structure technique is best suited. Crest height had been increased from $10 \mathrm{~cm}$ to $25 \mathrm{~cm}$ then the $C_{d}$ values also decreased from 0.82 to 0.50 for discharge decreased from 24 to $6 \mathrm{Ls}^{-1}$ under free flow conditions. The co-efficient of discharge for the different weirs under 60 per cent submergence conditions, if the increased crest height was from $10 \mathrm{~cm}$ to 25 $\mathrm{cm}$ then the $\mathrm{C}_{\mathrm{d}}$ values also decreased from 0.75 to 0.43 for 24 to $6 \mathrm{Ls}^{-1}$ discharge. Under 75 per cent submergence conditions, if the increased crest height was from $10 \mathrm{~cm}$ to $25 \mathrm{~cm}$ then the $\mathrm{C}_{\mathrm{d}}$ values also decreased from 0.7 to 0.42 for discharge decreased from 24 to $6 \mathrm{Ls}^{-1}$. Under 90 per cent submergence conditions, if the increased crest height was from $10 \mathrm{~cm}$ to $25 \mathrm{~cm}$ then the $\mathrm{C}_{\mathrm{d}}$ values also decreased from 0.69 to 0.42 for 24 to $6 \mathrm{Ls}^{-1}$ discharge. For $24 \mathrm{Ls}^{-1}$ discharge, the co-efficient of discharge has been decreased from 0.72 to 0.62 for increased submergence levels from 60 per cent to 90 per cent due to increase in contact surface area and friction and less discharge have low velocity of approach.

— KEY WORDS : Flume, Weirs, Co-efficient of discharge, Crest height, Discharges

- HOW TO CITE THIS PAPER : Rao, D. Sai Gangadhara, Satyanarayana, T.V. and Kumar, H.V. Hema (2014). Coefficient of discharge variation for different semi-circular weirs. Internat. J. Agric. Engg., 7(2) : 293-298. 